\title{
On the Possibility of Obtaining a High Resolution Relative Paleointensity Record of the Pringle Falls Excursion at the Type Locality of Pringle Falls, Oregon, USA
}

\author{
Emilio Herrero-Bervera \\ Paleomagnetics and Petrofabrics Laboratory, SOEST-Hawaii Institute of Geophysics and Planetology, \\ University of Hawaii at Manoa, Hawaii, USA \\ Email: herrero@soest.hawaii.edu
}

Received 15 November 2015; accepted 14 March 2016; published 17 March 2016

Copyright (C) 2016 by author and Scientific Research Publishing Inc. This work is licensed under the Creative Commons Attribution International License (CC BY). http://creativecommons.org/licenses/by/4.0/

(c) (i) Open Access

\section{Abstract}

In order to further understand the full vector excursional details of the geomagnetic field, a paleomagnetic and rock magnetic study of four sites has been conducted at the type locality of Pringle Falls, Oregon where 827 samples were drilled and spaced along a distance of $5 \mathbf{~ k m}$, for their detailed directional and relative paleointensity studies. The profiles have registered a high-resolution $(>10 \mathrm{~cm} / \mathrm{kyr}$ ) paleomagnetic record of the excursion (ca. $211+/ 13 \mathrm{ka}$ ) as recorded by diatomaceous lacustrine sediments. Remanence as well as induced magnetization experiments to investigate the reproducibility of the signal throughout the profiles have been conducted. In addition, low-field susceptibility vs. temperature analysis was performed indicating that the main magnetic carrier is pure magnetite (Curie point $575^{\circ} \mathrm{C}$ ). The magnetic grain size also has indicated Single Domain-Multi-Domain (SD-MD) magnetite. The demagnetization was done by alternating field (a.f.) experiments, and the mean directions were determined by principal component analyses. In addition, induced magnetic tests were done, such as magnetic susceptibility $(\chi)$ analyses, saturation IRM, anhysteretic remanent magnetization (ARM70) as well as the normalization of J17.5 mT/ARM70 to attempt to obtain relative paleointensity records of these sediments in question. The results of the induced rock magnetic tests such as the normalization studies indicate a direct correlation between the decrease of the relative paleointensity variations (i.e. lows) with respect to the directional changes. The detailed behavior of the paleosignal is highly consistent, since they are rapidly deposited sediments providing a detailed representation of the paleofield. The dissected VGP paths in $\mathbf{3}$ different phases are highly internally consistent and are defined by clockwise and anticlockwise loops traveling from the high northern latitudes over eastern North America and the North Atlantic to South America and then to high southern latitudes. They then return to the high northern latitudes through the Pacific and over to Kamchatka. This VGP behavior defines the geomagnetic signature of the Pringle Falls excursion as recorded at the type locality. 


\section{Keywords}

\section{Pringle Falls, Excursion, Lacustrine Sediments, Geomagnetic Signature}

\section{Introduction}

The discovery of the Pringle Falls excursion took place in the late 1980s. At the beginning of the identification of the excursion research, it was mistakenly identified as the Blake polarity episode [1] [2]. It was after the identification of the characteristic geomagnetic features recorded by the declination and inclination records and the research work done on the chronostratigraphy, geochronology and tephrachronology that documented two sites at Pringle Falls along the Deschutes River in Oregon (see Figure 1) that the excursion was officially described and established as a geomagnetic feature [3].

Subsequent research work was performed to correlate the directional geomagnetic signal from additional profiles drilled ( $\sim 837$ samples) along the Deschutes River spaced along a distance of $5 \mathrm{~km}$, for their detailed directional geomagnetic signature.

Thus far, the rock magnetic characterization as well as the entire directional analyses (i.e. declination and inclination) of the geomagnetic paleosignal of four widely spaced profiles has been completed and published recently [4].

The aim of this paper is an attempt to study the rock magnetic parameters such as the magnetic susceptibility $(\chi)$, the saturation isothermal remanent magnetization (SIRM) and the anhysteretic remanent magnetization (ARM) in order to characterize the relative paleointensity of the sediments in question at the type section of Pringle Falls, Oregon.

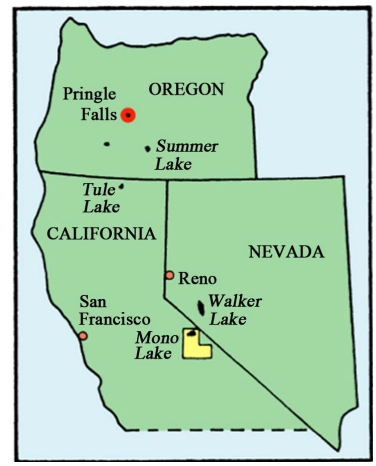

(a)

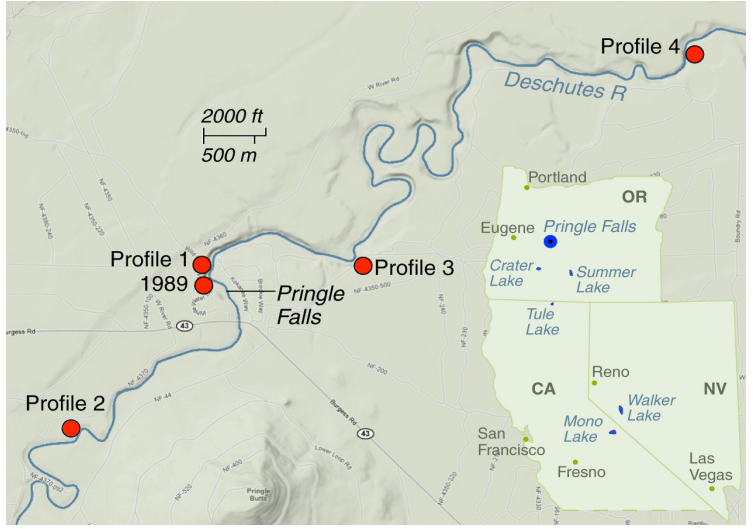

(b)

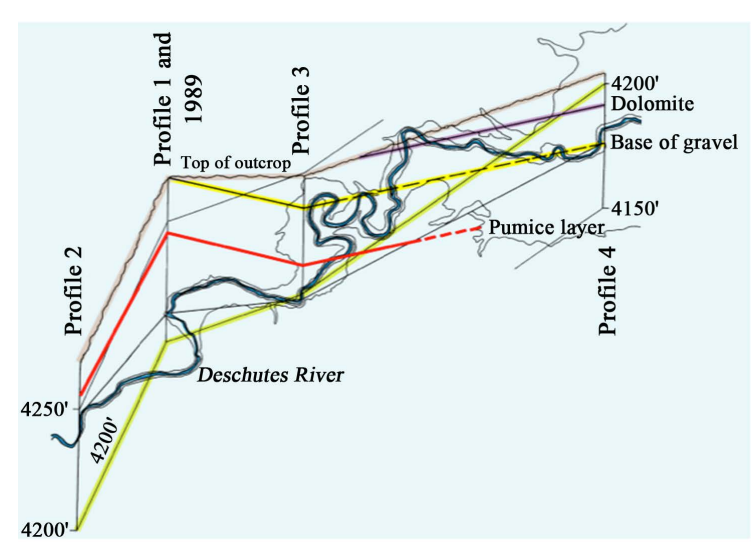

(c)

Figure 1. Location of the type locality of Pringle Falls profiles sampled along the Deschutes River Pringle Falls, Oregon USA (taken from Herrero-Bervera and Canon-Tapia, 2013). 


\section{Work up to Date at the Pringle Falls Type Sections}

It is presented here the obtained high-resolution record of the Pringle Falls "aborted reversal” that has been dated by means of 40Ar/39Aranalys is yielding an age of $211 \pm 13 \mathrm{ka}$ [3] and correlated along a $5 \mathrm{~km}$ segment in the Deschutes River area in Oregon. This paper shows a full vector description of the excursion by means of directions [4] and relative paleointensity measurements that will be part of the global geomagnetic polarity time scale. This record will be correlated to other stratigraphic markers such as ${ }^{18}$ Oxygen $/{ }^{16}$ Oxygen and other biostratigraphic proxies.

The directional results can be summarized as follows: The rock magnetic tests performed on the Pringle Falls samples such as the remanent magnetization of the four profiles, show an excellent magnetostratigraphic correlation of the main excursional features labeled as A, B and C present on the four records shown in Figure 2, and have been published relatively recently [4]. The directional results have been converted to virtual geomagnetic poles (VGPs) in order to compare the excursional characteristics of the profiles. Figure 3 shows the characteristic geomagnetic signature of the excursion. The results of only one site are displayed as "snap shots" of the aborted reversal paths as an initial/oldest and early phase corresponding to the geomagnetic feature " $\mathrm{A}$ " (see Figure 2), the subsequent intermediate middle phase " $B$ " and the final and youngest phase " $C$ ”. The arrows indicate the motion of the individual VGPs along the excursional paths showing the characteristic loops that define the unique geomagnetic signature of the Pringle Falls excursion at the type section. In order to prove that the VGP magnetic signature has been recorded by the four sites, Figure 4 shows the paths derived from the individual profiles and the intrabasinal correlation of the signature. As a result of the VGP correlation paths one can conclude that the paths are highly internally correlateable and consistent, and show very distinct clockwise loops traveling from high northern latitudes over the eastern part of the North American continent and the North Atlantic to South America with a fast motion to high southern latitudes and a subsequent return to high northern latitudes across the Pacific and over Kamchatka associated with the initial phase of the excursion, which corresponds to geomagnetic feature A. The other two geomagnetic features, such as B and C, corresponding to the middle and late stages of the evolution of the excursional field, have their own looping, indicating a complex non-dipolar behavior of the excursional field [4].

\section{An Attempt to Recover a Relative Paleointensity Record from the Pringle Falls Excursion at the Type Section}

One of the most important reasons to stud the detailed behavior of polarity transitions and aborted reversals is to determine the third component of the geomagnetic field vector, i.e. the paleointensity of the rapidly deposited Pringle Falls lacustrine sediments. In order to reconstruct the variability the strength of the geomagnetic field, one has to recur to the relative paleointensity (RPI) methodology [5]-[7] to obtain an estimate of the paleofield from sedimentary sections, like the Pringle Falls lacustrine profiles. The relative paleointensity method has the great benefit of the fact that potentially, the ultimate RPI records are relatively continuous and characterized by a more or less complete dating of the sedimentary sequences. Unfortunately, one of the drawbacks of the RPI method is that the exact strength of the local field intensity cannot be determined and only the relative fluctuations of the paleofield over certain periods of time can be determined. Most of the recent RPI results have been obtained from deep-sea sediments and from lake sediments particularly for the Holocene (i.e. 0 - 12,000 years before the present). The study of the relative paleointensity of lake sediments has rendered a very good understanding of the paleofield from different localities all over the world [8]-[19]. Still, the RPI studies of excursions of the geomagnetic field [20] recovered from lacustrine sediments are almost non-existent.

The type location at Pringle Falls offers the opportunity to recover the much needed RPI record. The rock magnetic properties of the Pringle Falls sediments that have indicated a single phase magnetic mineralogy carried by almost pure magnetite and very consistent magnetic grains sizes dominated by pseudo-single domain (PSD) magnetite [4] and the well-defined magnetization component carried by PSD magnetite with variations of less than a factor of ten in the magnetic concentration, satisfy the common standard criteria required for RPI studies [5]-[7] [20] [21]. Therefore, the results obtained for this study have indicated a good suitability of the sediments in question for the RPI experiments.

The NRM of the discrete samples were measured using the ScT and the 2G760 cryogenic SRM instruments. Susceptibility measurements of the samples were carried out with a Mini-Kappa bridge built by AGICO. Anhysteretic remanent magnetization (ARM) was acquired in a peak alternating field of $70 \mathrm{mT}$ and a $50 \mathrm{nT}$ DC bias 
PROFILE 2

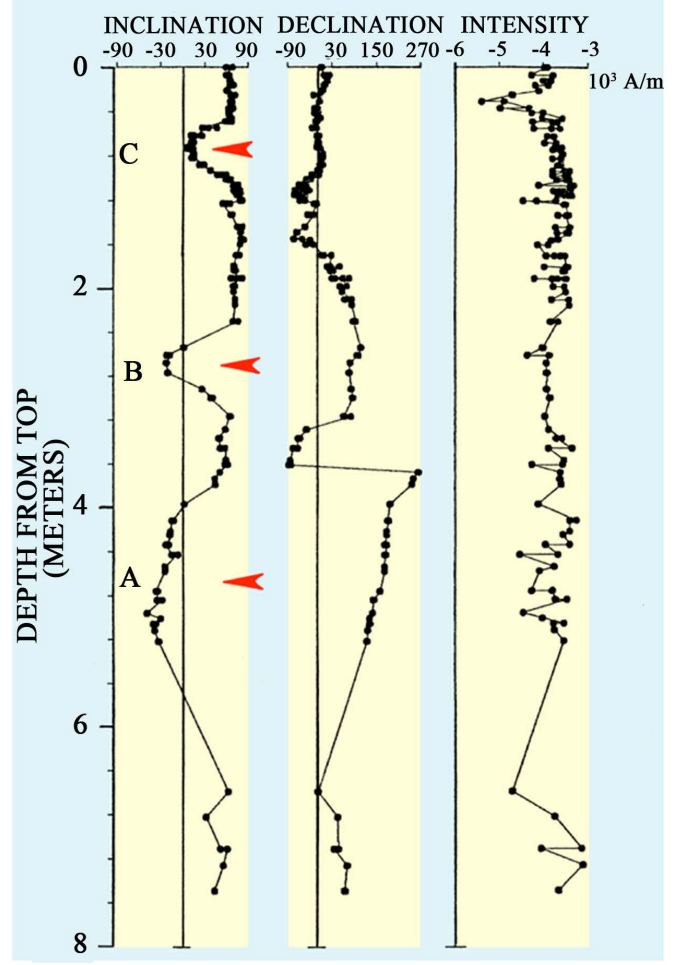

LA PINE, OREGON

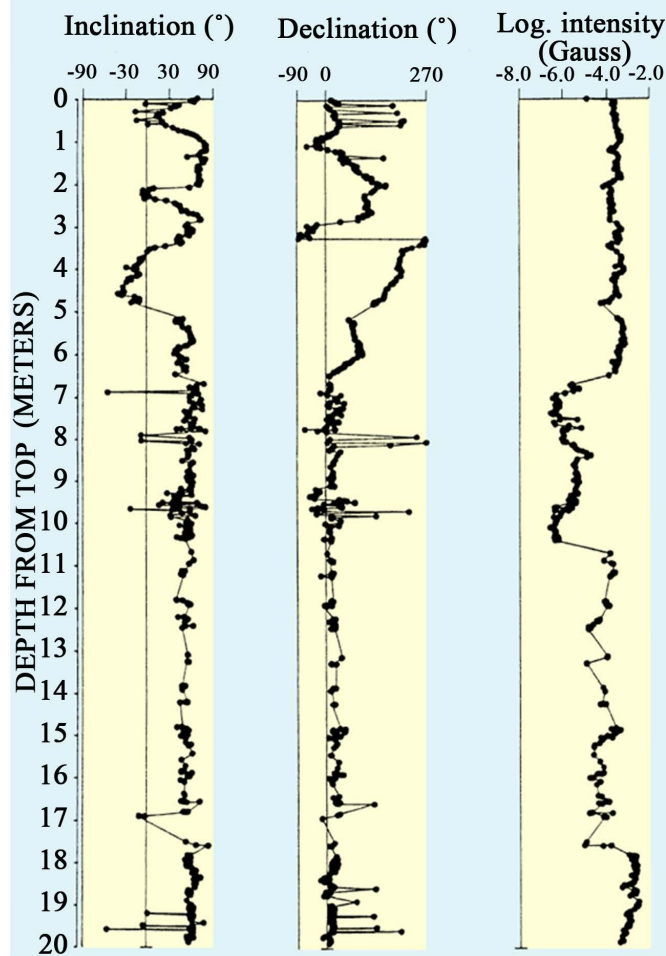

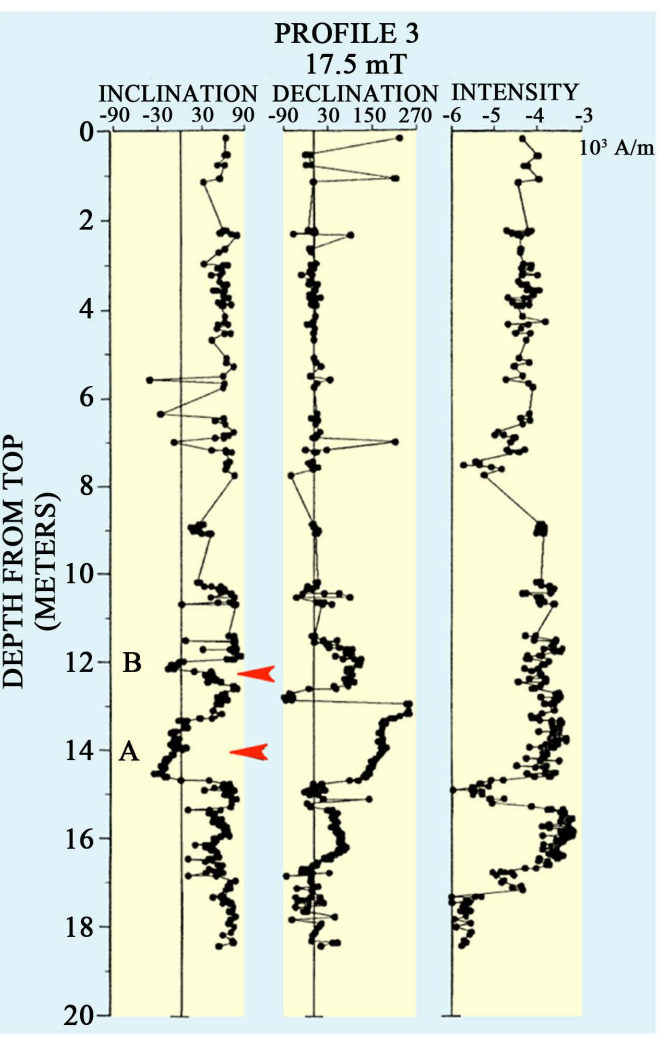

PROFILE 1

$17.5 \mathrm{mT}$

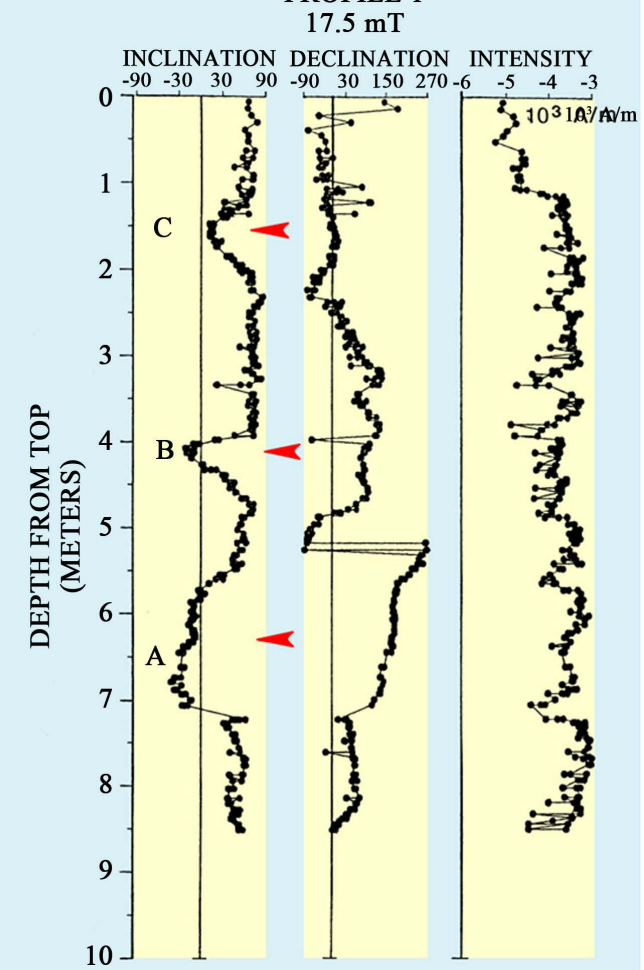

Figure 2. Magnetostratigraphic correlation of the directional (i.e. declination, inclination and intensity of magnetization) behavior of four profiles recorded at the Pringle Falls site, Oregon. The red arrows show the characteristic inclination geomagnetic features A, B and C of the Pringle Falls excursion (taken from Herrero-Bervera and Canon-Tapia, 2013). 

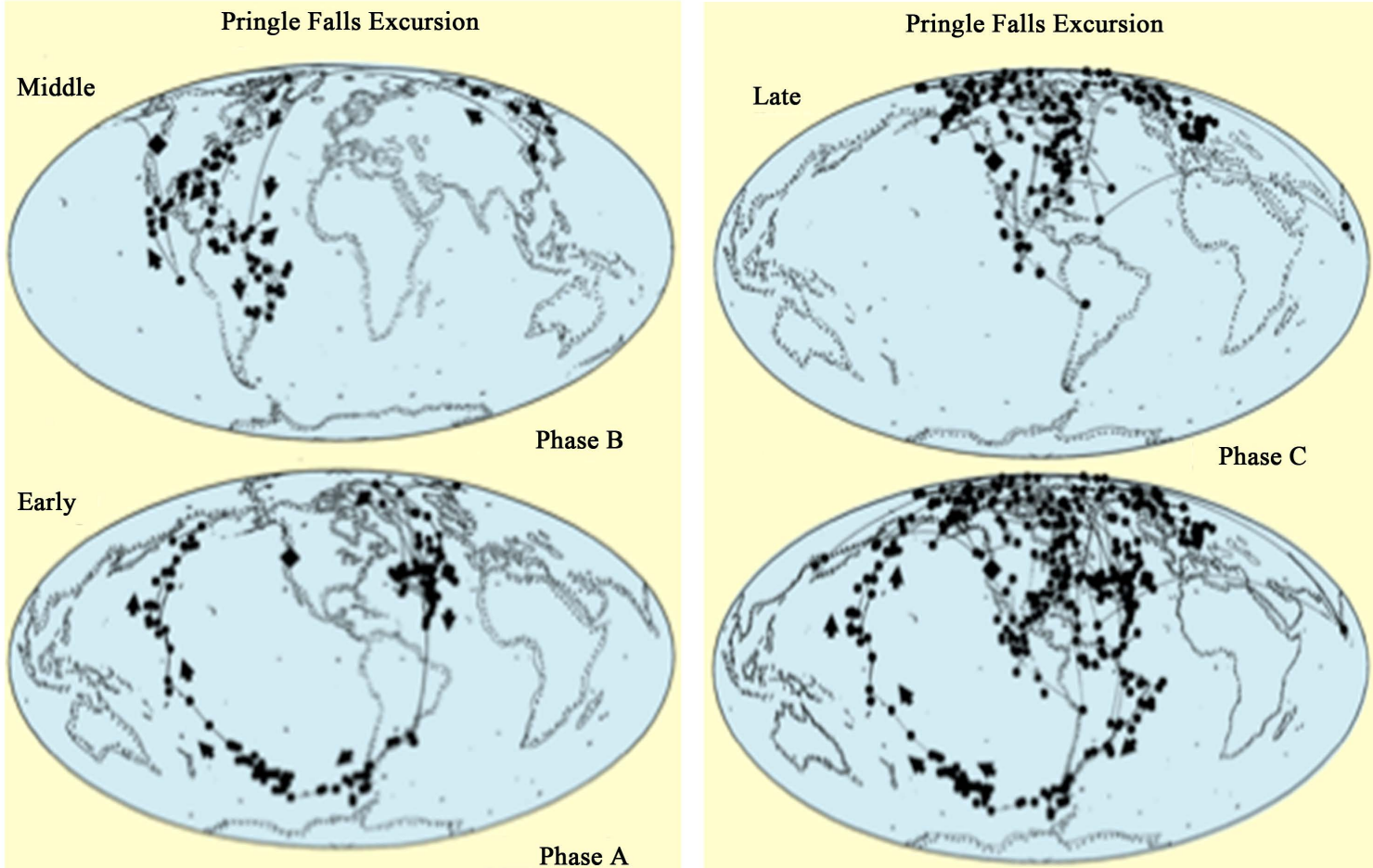

Figure 3. Virtual Geomagnetic Poles (VGPs) of the Pringle Falls excursion showing the "geomagnetic signature" that characterize the excursion at Pringle Falls, Oregon (taken from Herrero-Bervera and Canon-Tapia, 2013).
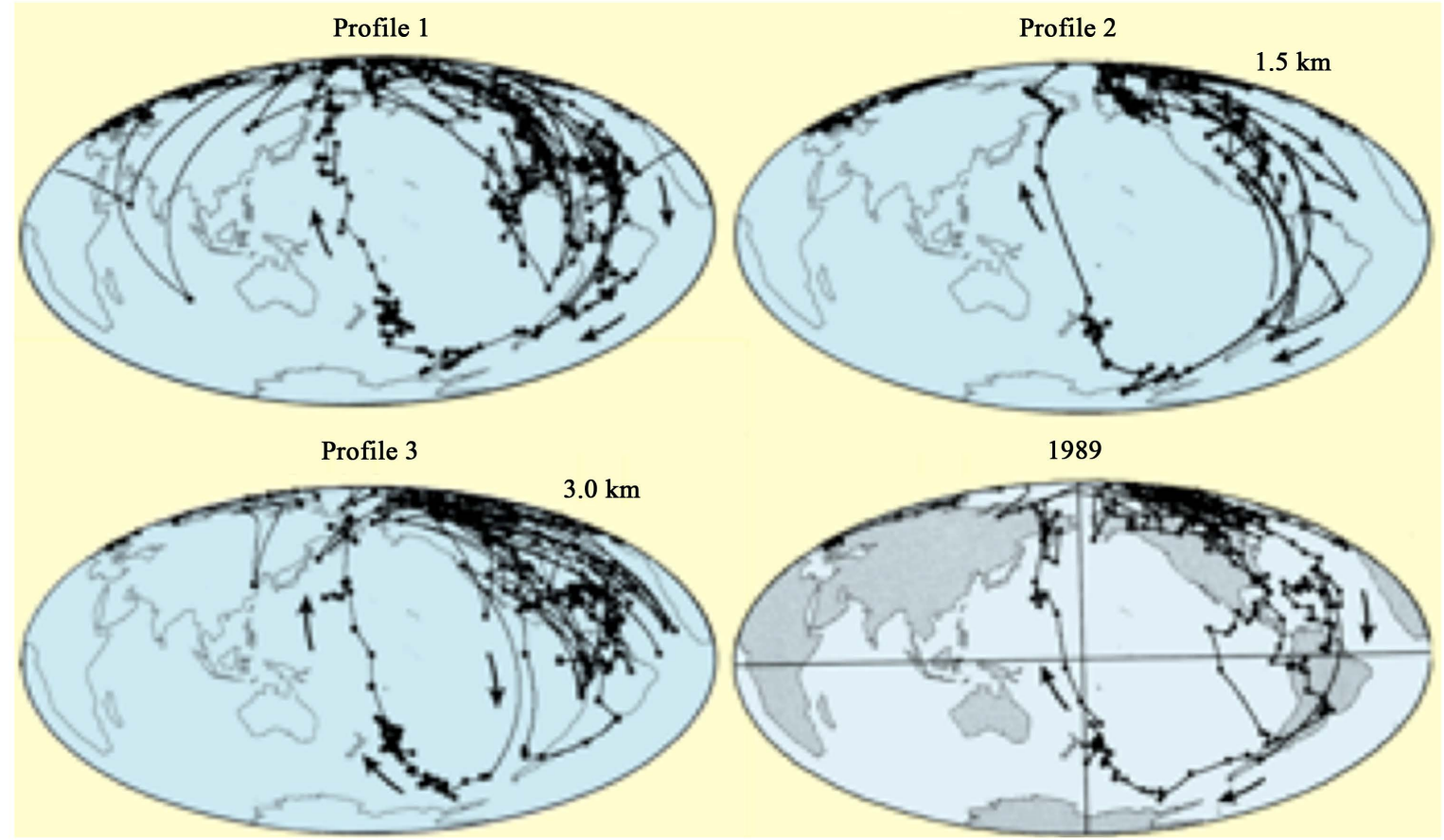

Figure 4. Individual Virtual Geomagnetic Pole (VGPs) paths of the four profiles at the type locality of Pringle Falls (taken from Herrero-Bervera and Canon-Tapia, 2013).

field, and saturation isothermal remanent magnetization (SIRM) was imparted to the samples using an SCT pulse magnetizer in a 1.2 Teslas field. All NRM and induced magnetization experiments were conducted at the 
Petrofabrics and Paleomagnetics Laboratory of the SOEST-HIGP at the University of Hawaii at Manoa.

Taking into consideration the results of the characteristic alternating field (AF)demagnetization experiments of the NRM directions [4], the RPI was generated using the results of NRM, ARM and SIRM after AF demagnetization was done at $17.5 \mathrm{mT}$ (i.e. NRM17.5mT, ARM17.5mT, and SIRM17.5mT).

Natural Remanent Magnetization magnetic (NRM), susceptibility ( $\chi$ ), Anhysteretic Remanent Magnetization (ARM) and Saturation Isothermal Remanent Magnetization (SIRM) experiments were carried out to attempt to investigate the strength of the paleofield during the Pringle Falls excursion.

\section{Relative Paleointensity Records}

In order to test the idea that during the Pringle Falls excursion at the type section, the strength of the geomagnetic field decreases during the "aborted reversal", then we have plotted up the NRM17.5mT, susceptibility, J17.5mT/ARM70, and SIRM1.2T of the original profile [2] against the inclination records of the four profiles in question showing the characteristic geomagnetic features (i.e. A, B and C) (see Figure 5). In addition to that comparison, show in Figure 6 the shows the results of the other three profiles.

\section{Discussion}

It has been discussed and concluded that the Pringle Falls excursion recorded globally in the 205 - 225 ka interval [22] and has been recorded not only at the Pringle Falls type section but at other widely separated and far removed localities [4] [23]-[25]. That makes the excursion a world-wide "aborted reversal" that has also been correlated to stage $7 \beta$ of ODPSite1062 [26].

However, very few of these records have firmly established the correlation between the directional geomagnetic excursional features of Pringle Falls to the decrease of the intensity of the paleofield [3] [24]-[28]. Ourrock magnetic experiments of both the remanence and the induced magnetization results have indicated a good correlation of the directional features to the J17.5mT, magnetic susceptibility $(\chi)$, normalized J17.5mT/ARM70 as
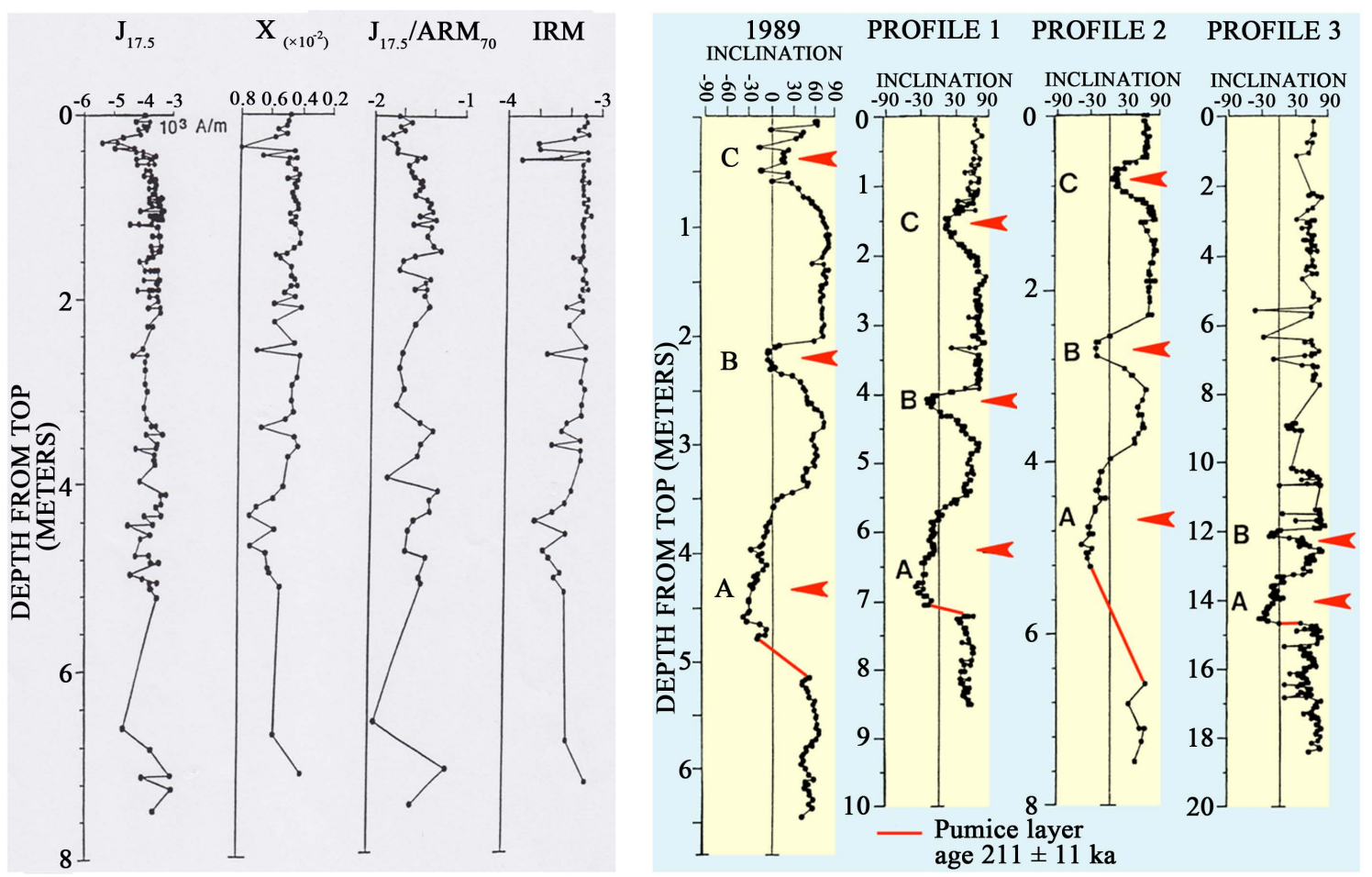

Figure 5. Stratigraphic plot of Intensities (J), susceptibility (x), normalized intensity (at $17.5 \mathrm{mT}$ ) with respect to ARM (J/ARM), Anhysteretic Remanent Magnetization (ARM) (a.f. at $70 \mathrm{mT}$ in a DC field of 0.05 and Saturated Isothermal Remanent Magnetization (sIRM)). Notice the decreased normalized field is depicted by $\mathrm{J}_{17.5 \mathrm{mT}} / \mathrm{ARM}_{70}$ which is the best normalized parameter for the Pringle Falls sediments (figures taken from Herrero-Bervera and Helsley, 1993 and Herrero-Bervera and Canon-Tapia, 2013, respectively). 

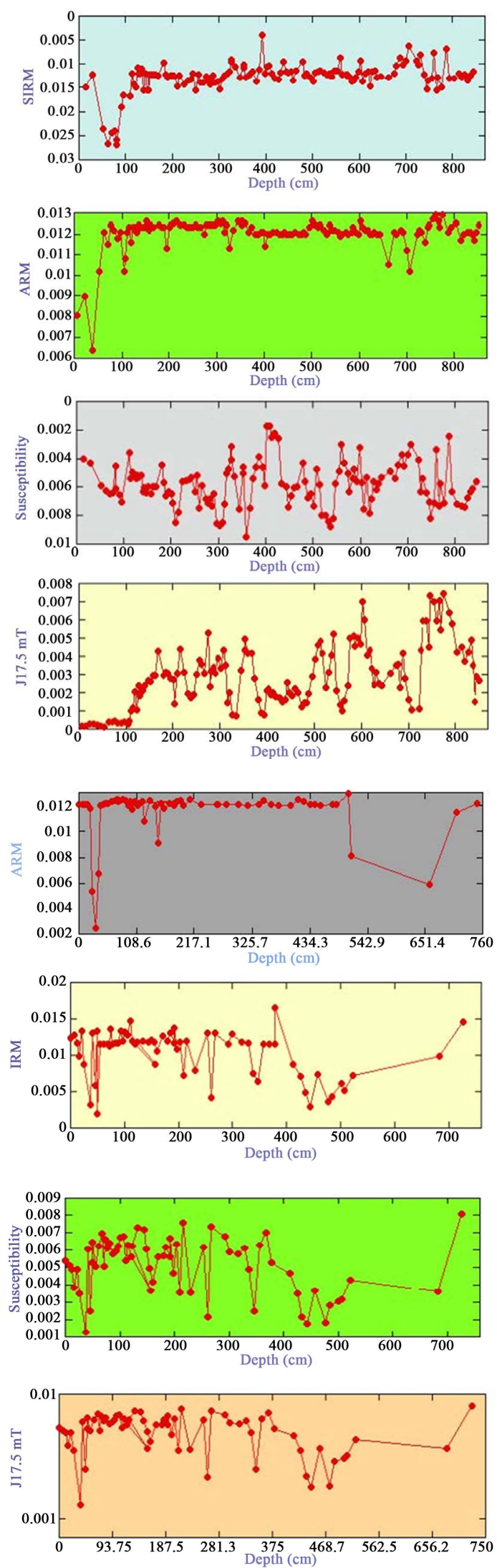

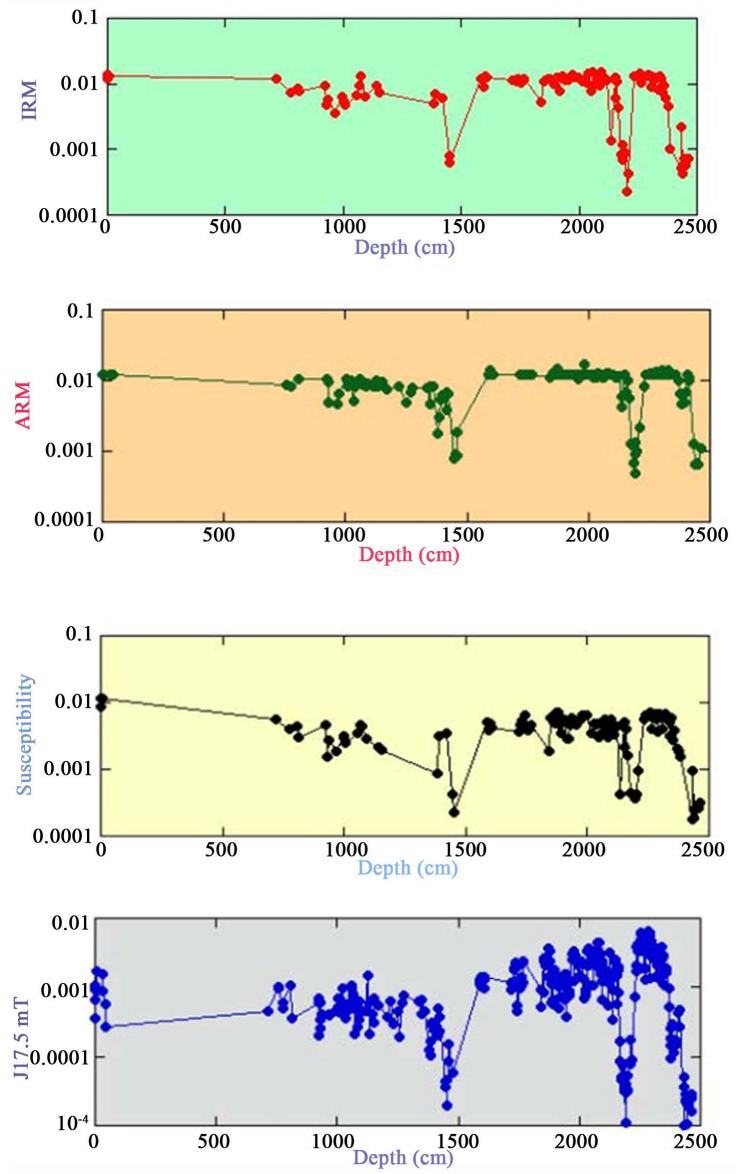

\begin{abstract}
Figure 6. Diagrams showing the results of the relative Paleointensity (RPI) experiments performed on Profiles 1 (first corner), Profile 2 (second corner) and Profile 3 (third corner). The experiments performed were the demagnetized intensity of magnetization of the samples (J), the Anhysteretic Remanent Magnetization (ARM), magnetic susceptibility and Saturation Isothermal Remanent Magnetization (SIRM).
\end{abstract}

well as SIRM correlations with primarily the inclination geomagnetic features A, B and C, where there is a clear decrease of these rock magnetic parameters in relation to the directional changes (see Figure 5). In addition, Figure 6 shows the correlation between the NRM17.5mT and the other rock magnetic results. It is important to point out that the four records show a very good agreement of the diminution of the presumably geomagnetic field with respect to the demagnetized NRM records. The most salient and clear decrease of the relative paleointensity with respect to the directional features are represented by Profiles 2 and 3 where one can see the conspicuous concave down peaks of the three induced rock parameters to the NRM17.5mT (see Figure 6).

\title{
6. Conclusion
}

The conclusion of this work indicates that the there is a marked directional instability of the very fast deposited lacustrine Pringle Falls sediments (i.e. $>10 \mathrm{~cm} / \mathrm{k}$ year) that characterizes the geomagnetic field during the so called "excursions" or "aborted reversals". In addition to the "anomalous" directional fluctuations one can observe that during the excursional behavior of the geomagnetic field, the intensity of the magnetic field decreases substantially. This is the case of the Pringle Falls excursion records in this paper (see Figures 2-6). As reported by [22], "Polarity excursions are observed at time of low paleointensity when the strength of the axial dipole is reduced by a factor of about 5, and reduced relative to the non-axialdipole (NAD) field. [29] have shown that the critical Reynolds number $(R c)$ for the onset of core convection is very sensitive to the poloidal field, and the 
strength of core convection varies wildly in response to changes in magnetic field strength particularly during intensity minima". Thus far, the results presented here indicate that the induced rock magnetic experiments prove that the type locality lacustrine sediments that registered the Pringle Falls excursion are suitable recorders of the instabilities of the paleofield during the "aborted reversal" of this study.

\section{Acknowledgements}

We are very grateful to Mr. James K. S. Lau for his laboratory assistance. Financial support to Emilio HerreroBervera was provided by SOEST-HIGP and the National Science Foundation grants EAR-9909206, EAR-INT9906221, EAR-0207787, EAR-0213441, EAR-0510061, EAR-1215070. This is a SOEST contribution \#9578, HIGP contribution \#2184.

\section{References}

[1] Herrero-Bervera, E., Helsley, C.E., Hammond, S.R. and Chitwood, L.A. (1989) A Possible Lacustrine Paleomagnetic Record of the Blake Episode from Pringle Falls, Oregon, U.S.A. Physics of the Earth and Planetary Interiors, 56, 112123. http://dx.doi.org/10.1016/0031-9201(89)90041-1

[2] Herrero-Bervera, E. and Helsley, C.E. (1993) Global Paleomagnetic Correlation of the Blake Geomagnetic Polarity Episode. In: Aissaoui, D.M., McNeill, D.F. and Hurley, N.F., Eds., Application of Paleomagnetism to Sedimentary Geology, SEPM Special Publications, 49, 71-82.

[3] Herrero-Bervera, E., Helsley, C.E., Sarna-Wojcicki, A.M., Lajoi, K.R., Meyer, C.E., McWilliams, M.O., Negrini, R.M., Turrin, B.D., Nolan, J.M. and Liddicoat, J.C. (1994) Age and Correlation of a Paleomagnetic Episode in the Western United States by 40Ar/39Ar Dating Tephrochronology: The Jamaica, Blake, or a New Polarity Episode? Journal of Geophysical Research, 99, 24091-24103. http://dx.doi.org/10.1029/94JB01546

[4] Herrero-Bervera, E. and Canon-Tapia, E. (2013) On the Directional Geomagnetic Signature of the Pringle Falls Excursion Recorded at Pringle Falls, Oregon, USA. Geological Society, London, Special Publications Published Online.

[5] Levi, S. and Banerjee, S.K. (1976) On the Possibility of Obtaining Relative Paleointensities from Lake Sediments. Earth and Planetary Science Letters, 29, 219-226. http://dx.doi.org/10.1016/0012-821X(76)90042-X

[6] King, J.W., Banerjee, S.K. and Marvin, J. (1983) A New Rock Magnetic Approach to Selecting Sediments for Geomagnetic Paleointensity Studies: Application to Paleointensity for the Last 4000 Years. Journal of Geophysical Research, 88, 5911-5921. http://dx.doi.org/10.1029/JB088iB07p05911

[7] Tauxe, L. (1993) Sedimentary Records of Relative Paleointensities of the Geomagnetic Field: Theory and Practice. Reviews of Geophysics, 31, 319-354. http://dx.doi.org/10.1029/93RG01771

[8] Creer, K.M., Tucholka, P. and Barton, C.E. (1983a) Paleomagnetism of Lake Sediments. In: Creer, K.M., et al., Eds., Geomagnetism of Baked Clays and Recent Sediments, Elsevier, Amsterdam, 172-197.

[9] Creer, K.M., Valencio, D.A., Sinito, A.M., Tucholka, P. and Vilas, J.F. (1983b) Geomagnetic Secular Variations 0 14000 Years BP as Recorded by Lake Sediments from Argentina. Geophysical Journal of the Royal Astronomical Society, 74, 199-221. http://dx.doi.org/10.1111/j.1365-246X.1983.tb01877.x

[10] Constable, C.G. and McElhinny, M.W. (1985) Holocene Geomagnetic Secular Variations Records from North-Eastern Australian Lake Sediments. Geophysical Journal of the Royal Astronomical Society, 81, 103-120. http://dx.doi.org/10.1111/j.1365-246X.1985.tb01353.x

[11] Gogorza, C.S.G., Irurzun, M.A., Sinito, A.M., Lisé-Pronovost, A., St-Onge, G., Haberzettl, T., Ohlendorf, C., Kastner, S. and Zolitschka, B. (2012) High-Resolution Paleomagnetic Records from Laguna PotrokAike (Patagonia, Argentina) for the Last 16,000 Years. Geochemistry, Geophysics, Geosystems, 13, Q12Z37. http://dx.doi.org/10.1029/2011GC003900

[12] Lund, S.P. and Banerjee, S.K. (1985) Late Quaternary Field Secular Variation from Two Minnesota Lakes. Journal of Geophysical Research, 90, 803-825. http://dx.doi.org/10.1029/JB090iB01p00803

[13] Verosub, K.L., Mehringer, P.J. and Waterstraat, P. (1986) Holocene Secular Variations in Western North America Palaeomagnetic Record from Fish Lake, Harney County, Oregon. Journal of Geophysical Research, 91, 3609-3623. http://dx.doi.org/10.1029/JB091iB03p03609

[14] Peng, L. and King, J.W. (1992) A Late Quaternary Geomagnetic Secular Variation Record from Lake Waiau, Hawaii, and the Question of the Pacific Non-Dipole Low. Journal of Geophysical Research, 97, 4407-4424. http://dx.doi.org/10.1029/91JB03074

[15] Stockhausen, H. (1998) Geomagnetic Palaeosecular Variation (0 - 13000 yr BP) as Recordedin Sediments from Three Maar Lakes from the West Eifel (Germany). Geophysical Journal International, 135, 898-910. 
http://dx.doi.org/10.1046/j.1365-246X.1998.00664.X

[16] Brandt, U., Nowaczyk, N.R., Ramrath, A., Brauer, A., Mingram, J., Wulf, S. and Negendank, J.F.W. (1999) Paleomagnetism of Holocene and Late Pleistocene Sediments from Lago di Mezzano and Lago Grance di Monticchio (Italy): Initial Results. Quaternary Science Reviews, 18961-18976.

[17] Frank, U., Nowaczyk, N.R., Negendank, J.F.W. and Melles, M. (2002) A Paleomagnetic Record from Lake Lama, Northern Central Siberia. Physics of the Earth and Planetary Interiors, 133, 3-20. http://dx.doi.org/10.1016/S0031-9201(02)00088-2

[18] Ojala, A.E.K. and Saarinen, T. (2002) Palaeosecular Variation of the Earth's Magnetic Field during the Last 10000 Years Based on the Annually Laminated Sediment of Lake Nautajärvi, Central Finland. Holocene, 12, 391-400. http://dx.doi.org/10.1191/0959683602hl551rp

[19] Yang, X., Heller, F., Yang, J. and Su, Z. (2009) Paleosecular Variations Since 9000 yr BP as Recorded by Sediments from Maar Lake Shuangchiling, Hainan, South China. Earth and Planetary Science Letters, 288, 1-9. http://dx.doi.org/10.1016/j.epsl.2009.07.023

[20] Stoner, J.S. and St-Onge, G. (2007) Magnetic Stratigraphy in Paleoceanography: Reversals, Excursions, Paleointensity and Secular Variation. In: Hillaire-Marcel, C. and de Vernal, A., Eds., Proxies in Late Cenozoic Paleoceanography. Elsevier, Amsterdam, 99-138.

[21] Verosub, K.L., Herrero-Bervera, E. and Roberts, A.P. (1996) Relative Geomagnetic Paleointensity across the Jaramillo Subchron and the Matuyama/Brunhes Boundary. Geophysical Research Letters, 23, 467-470. http://dx.doi.org/10.1029/96GL00454

[22] Channell, J.E.T. (2006) Late Brunhes Polarity Excursions (Mono Lake, Laschamp, Iceland Basin ard, Pringle Falls) Recorded at ODP Site 919 (Irminger Basin). Earth and Planetary Science Letters, 244, 378-393. http://dx.doi.org/10.1016/j.epsl.2006.01.021

[23] McWilliams, M.O. (2001) Global Correlation of the 223 ka Pringle Falls Event. International Geology Review, 43, 191-195. http://dx.doi.org/10.1080/00206810109465007

[24] Singer, B.S., Jicha, B.R., Kirby, B.T., Geissman, J.W. and Herrero-Bervera, E. (2008) 40Ar/39Ardatinglinks Albuquerque Volcanoes to the Pringle Falls Excursion and the Geomagnetic Instability Time Scale. Earth and Planetary Science Letters, 267, 584-595. http://dx.doi.org/10.1016/j.epsl.2007.12.009

[25] Valet, J.P., Plenier, G. and Herrero-Bervera, E. (2008b) Geomagnetic Excursions Reflect an Aborted Polarity State. Earth and Planetary Science Letters, 274, 472-478. http://dx.doi.org/10.1016/j.epsl.2008.07.056

[26] Lund, S., Stoner, J.S., Channell, E.T. and Acton, G. (2006) A Summary of Brunhes Paleomagnetic Field Variability Recorded in Ocean Drilling Program Cores. Physics of the Earth and Planetary Interiors, 156, 194-204. http://dx.doi.org/10.1016/j.pepi.2005.10.009

[27] Guyodo, Y. and Valet, J.P. (1999) Global Changes in Intensity of the Earth’s Magnetic Field during the Past 800 kyr. Nature, 399, 249-252. http://dx.doi.org/10.1038/20420

[28] Valet, J.P., Meynadier, L. and Guyodo, Y. (2005) Geomagnetic Field Strength and Reversal Rate over the Past 2 Million Years. Nature, 435, 802-805. http://dx.doi.org/10.1038/nature03674

[29] Zhang, K. and Gubbins, D. (2000) Is the Geodynamo Process Intrinsically Unstable? Geophysical Journal International, 140, F1-F4. http://dx.doi.org/10.1046/j.1365-246x.2000.00024.x 